\title{
Cecilia Panti and Nicola Polloni (eds.), Vedere nell'ombra. Studi su natura, spiritualità e scienze operative offerti a Michela Pereira, Micrologus Library 90, Firenze, SISMEL - Edizioni del Galluzzo, 2018, 430 pp., ISBN: 9788884508133 . Cloth $€ 62$
}

\author{
Reseñado por LAURA CESCO-FRARE \\ University of Salerno \\ 1.cescofrare@studenti.unisa.it
}

Without any doubt, Michela Pereira has been a pioneer in many a field of Medieval philosophy; starting from the early Seventies, Pereira has devoted her intellectual career to redefine the importance of those unrecognized domains that lay in between natural philosophy and Medieval science, such as astronomy, medicine and, above all, alchemy. Her interest in seldom treated intellectual figures and their historical and theoretical interpretations brought Pereira to expand her investigation to Medieval female thinkers and matriarchal studies. Thus, her area of expertise is wide and analysed many late Medieval thinkers, touching, among others, Ramon Llull, Hildegard of Bingen and Roger Bacon.

The present volume Vedere nell'ombra («Seeing in the shadow»), edited by Cecilia Panti and Nicola Polloni, was offered to Pereira as a gift for her seventieth birthday. The editors faced the arduous task of bringing together in a cohesive book an astounding variety of topics and essays. Considering the variousness of Pereira's interests, it is no wonder that the miscellany covers a remarkable timespan, from the High Middle Ages to the 20th century. Moreover, this diversity is not only due to the topics chosen by each author, but it is also highlighted by the different languages employed (Italian, English, Spanish) and the several kinds of contributions collected, from detailed studies to editions of brief texts, from historiographical analysis to descriptions of manuscripts.

However, even if the twenty-eight papers that compose this volume touch upon many different topics, there are some key concepts that give order to a collection that otherwise would have seemed poorly cohesive. One of these fils rouges is the focus on less explored thinkers and subjects, which is consistent with Pereira's line of research; this approach highlights a sort of «hidden side» of the history of philosophy, where thoughts and issues that are generally left in the shadow are analysed and brought to the light letting the reader "see in the shadow», as the title promised.

This operation may be implicit in some of the papers, but it is noticeably a Leitmotif of the miscellany. Thus, this volume has the merit to make evident the strains and conflicts hidden in the folds of the official narration of the history of philosophy, starting from the areas which Pereira favoured - the subheading suggests three macro-topics, namely nature, spirituality, and operative sciences. In describing the path that the collection invites us to follow, we will present each contribution mostly in a chronological order, which is the choice of the editors as well. This choice may accentuate the heterogeneity of the 
miscellany, but it is by far the less disorienting parameter and it helps the reader considering the variety of this work as one of its strong points, rather than a structural weakness.

The first two essays deal with a kind of friction which is one of the cornerstones of philosophical thought, that is the relationship between body and soul. Alessandro Linguiti (Siena) approaches the problem in the Chaldaic soteriology, where the human being undergoes a process of purification that detaches him from the materiality of the body for the soul to reach the intelligible world. Linguiti analyses the sources of the Chaldaic tradition and, above all, the explanations of fragment 128 proposed by Michael Psellos and other ancient and modern interpreters. Another aspect of the contraposition soul/body is considered by Paola Carusi (Roma La Sapienza) in the Arabic alchemical literature concerning the notion of «subtle bodies»; this concept can be found applied both to physical elements hidden in corporeal beings, such as water, oil, and sap and to the soul inside the body. Inspecting the ambivalence of its use in different Arabic theological schools, especially the Mu'tazila, it is highlighted that the soul as a subtle body may be linked to the Nazzamian theory of latency. In considering the sources that inspired both alchemists and theologians to embrace this physical conceptualization of the soul, Carusi suggests Aristotle and the Aristotelian commentators as the possible remote filter through which all the discussions - even those concerning the physiologoi - may have passed.

Another important philosophical pairing, with a long tradition of thought, is the one composed by faith and reason; the contribution of Pinella Travaglia (Milano) describes the analogous attempt of al-Ghazali and of Bernard of Clairvaux to bridge the gap between faith and reason and to treat both of them as a structural part of human being. Considering the different backgrounds of the two writers, the paper analyses, on the one hand, the section of The Revival of the Religious Sciences (1095 - early 12th century) dedicated to love, longing, intimacy, and contentment for God by al-Ghazali and, on the other, the book De diligendo Deo (1132-1135) written by Bernard. Both works delineate an itinerary of love that gradually moves closer to God - in order to see Him (visio), for the Muslim theologian, or to reunite with Him (unio), for the abbot of Clairvaux. Both authors take into consideration the different ways of knowing and they recognize the role of reason in the consecutive steps of the process. However, in the final stages of the itinerary, men are destined to admit the limits of human reason, which are due to their own nature, and to recognize the primacy of Revelation - for this, the attempt to overcame the contrast between faith and reason is solved subordinating the latter to the former, which may not look like a solution at all.

Concerning the limits of men, two essays explore some peculiar application of the contrast between the perfection of human life in Eden and the postlapsarian condition of the homo viator. In the contribution of Silvana Vecchio (Ferrara), the difference between these two statuses is sketched by considering the medieval observations of theatrical performances: on the one hand, Arnold of Bonneval (first half of $12^{\text {th }}$ century) contrasts the «theatre of nature» offered by the marvels of Eden to Adam and the vague efforts of histrionic plays to recreate in the audience the same joy the first man felt in the Garden. The comparison between the two experiences - between the genuine reality of the prelapsarian world, 
where things signified themselves (allusio), and the fake pantomime of men (illusio) - recalls the harsh judgments expressed not only by Augustine of Hippo and Tertullian, but also by Plato and his followers. On the other hand, Hugh of Saint Victor tries to purify the theatrical art: in the Didascalicon, the ars theatrica is listed among the mechanical arts and it is considered from a theoretical point of view, while the performances of mimes and histrionic players are condemned according to the Christian tradition.

The hidden dangers of the postlapsarian life are also addressed in the paper of Carla Casagrande (Pavia), focused on the Liber de humanis moribus per similitudines, traditionally (and incorrectly) attributed to Anselm of Canterbury. The first part of the Liber, directed to a monastic audience, consists in a psychological analysis that considers the Will in relation to the external senses and the inner wits; secondly, the author lists the numerous sins in which men may run into; lastly, Anselm describes the lifestyle of monks and which virtues and vices they generally possess. The attempt to classify human faults is developed starting from a sound psychological background and it betrays the desire to propose both a scientific approach on the matter and a useful guide to those who chose to become monks.

This strain to achieve perfection - or, the highest level of perfection attainable by a human being -, is evident in the works of Marta Cristiani (Roma Tor Vergata) and of Georgina Rabassó and Rosa Rius Gatell (Barcelona) too. These two papers, along with the contribution of Peter Dronke (Cambridge), focus on Hildegard of Bingen, one of the authors Pereira examined the most during her career. While Dronke suggests the attribution to Hildegard of a text that can be identified as the Testamentum propheticum, further speculating on the nature of the Wiesbaden Codex (Riesenkodex), the other two papers focus on the peculiar use of allegories in Hildegard of Bingen's Liber divinorum operum and Ordo virtutum. Examining the first of these works, Cristiani describes the nuptial dress worn by Justice, that is embroidered with jewels of symbolic value crafted by the Apostles; Hildegard uses these allegorical figures to represent the harmony between aesthetics and virtues, so that striving for elegance has both an aesthetic and an ethical meaning. The allegory is also employed in the Ordo virtutum, where, as traced by Rabassó and Rius Gatell, the Soul follows its path towards God while resisting the temptation of the Devil with the help of the Virtues, two elements that embody the forces moving the universe.

From Germany to Spain, the paper of Nicola Polloni (Durham) deals with an example of transformation proposed by Dominicus Gundissalinus in his De processione mundi, namely the transition from water to stone. Whether this case of mutation comes from alchemical sources or not is one of the questions this essay discusses; while a similar example can be identified in other authors as Calcidius, William of Conches and Herman of Carinthia, Polloni suggests that the specific source of Gundissalinus is the Arabic version of Avicenna's De generatione et corruptione.

Another kind of strain is that between earthly love and celestial love. Francesco Santi (Cassino) analyses this matter in his contribution on Folc of Marseille and James of Vitry's friendship: their bond is evident considering not only their autobiographies, but also the 
Vita Marie de Oegnies, written by James and dedicated to Folc, who had favoured its writing. Both Folc's conversion (former troubadour who became a Cistercian monk) and James' work point to the consideration of two kinds of love, the troubadoric one and the one linked to the school of Saint Victor. Instead of an opposition between the two, the essay highlights their mutual connection, which allows the combination of spiritual zeal and physical action that can be found in the phenomenon of the Crusades.

Love is also the main topic of the paper of Cecilia Panti (Roma Tor Vergata): it considers the female literary stereotypes that can be seen in the De vetula, a pseudo-Ovidian poem that feigns classic references, but it is, instead, medieval for dating and sensibility. The description of the three possible kinds of woman (virgo, nupta, vidua) is situated in the context of the pleasures experienced indoor, in a precise classification of the delights that do not fully satisfy the poet's appetite. While the figure of the vetula serves traditionally as a comic relief, the non-classical features of this work are clear in its final part, where Ovid, disappointed by the physical decay of the object of his desire, undergoes his own mutation: if he cannot find solace and gratification in the pleasures of the flesh, he will turn to the pleasures of the intellect, converting to the Christian faith. The last female figure presented to the reader is, in fact, the Virgin Mother, to which the conclusive hymn is dedicated.

As anticipated before, the heterogeneity of this volume is evident not only because of the variety of contents, but also for the different kinds of contributions it offers to the reader. Following the structure of the miscellanea, the next two essays focus on textual editions or transcripts: the contribution of Gian Carlo Garfagnini (Firenze) revolves around the transcript of the preface and of the first two chapters of the Mythographus Vaticanus Tertius (MS Naz. II. VI.2, Biblioteca Nazionale Centrale di Firenze); this transcript is meant to be the first step toward a critical edition of the Latin text. Paola Bernardini (Siena) gives both a detailed introduction to and the critical edition of a quaestio taken from an anonymous commentary on the Aristotelian De anima (MS Todi, Biblioteca Comunale 23 , fols. $124 \mathrm{ra}-162 \mathrm{vb}$ ). The core of the question is whether a sinner suffers physically from hellfire or not, a controversy that became famous at the end of the Sixties of 13th century because of the dispute between Siger of Brabant and Thomas Aquinas; though seemingly secondary, the quaestio indeed addressed a central problem, namely how a physical element such as fire could act upon the sinner's soul, which is incorporeal.

Two essays are then dedicated to Roger Bacon and his relationship with Peter John Olivi, some authors among those Pereira studied. Jeremiah Hackett (South Carolina) proposes the identification of the Iuvenis Iohannes, a young scholar who was tasked with bringing the Opus maius and other works to Pope Clement IV and explaining their contents in Bacon's stead, with Peter John Olivi. By comparing these two thinkers, Hackett skilfully traces the possibility of this identification, analysing both the textual references and the recent secondary literature on the Baconian theory of perception and vision (as, for instance, the scholarly work of Pasnau and Toivanen). As for the other contribution, taking her leave from the account of the rationes seminales given by Bacon, Anna Rodolfi 
(Firenze) examines the position of Peter John Olivi on the matter. Olivi faces the problem of the rationes seminales from a twofold perspective: firstly, he recalls analytically the traditional arguments proposed by their supporters, providing a theoretical criticism to the question; secondly, he applies a textual exegesis of some Augustinian passages, proposing a new interpretation that allows him to consider the rationes seminales not as formal elements intrinsic to matter, but as the capability of matter to be transformed into a composed entity.

Pereira's attention to Medieval female thinkers was not limited to Hildegard of Bingen only; another author she focused on was Marguerite Porete, whom the contribution of Elisa Chiti (SISMEL) is dedicated to. Starting from a sentence originally found in the Liber XXIV philosophorum and quoted by Porete in her Miroir des simples âmes, this paper examines the Neoplatonic concepts present in Marguerite's work, particularly in her description of a peculiar mystic union with God (mystica speculativa). Furthermore, both textual sources and original innovations are considered in approaching Marguerite's thought and her mystical phenomenology.

Delving in the second half of this volume, the next essays deal with topics and authors mostly linked to history of medicine and of alchemy, which are Pereira's main interests of choice. The contribute of Lola Badia, Joan Santanach and Albert Soler (Barcelona) addresses how the concepts of time and space are implicitly employed by Ramon Llull in his work Romanç d'Evast e Blaquerna. While Llull leaves history and geography out of his Arbor scientiae and his other texts on the classification of sciences, this novel treats both: on the one hand, it presents a clear theological concept of history by following Pope Blaquerna's lifetime and adventures; on the other hand, geography permeates the plot of this novel, which is based on the hero's journey, as it employs geographical references for religious and missionary reasons.

Llull's production is taken into consideration also by Gabriella Pomaro (SISMEL), who focuses on the earliest Llullian philosophical works. In her paper, Pomaro describes accurately the codicological structure of two miscellaneous Italian manuscripts (that is, MS Fermo, Biblioteca Comunale 19 and MS Milano, Biblioteca Ambrosiana P.198 sup.). Another codicological description is offered by Agostino Paravicini Bagliani, who gives an accurate account of a codex of the Speculum Astronomiae traditionally ascribed to Albertus Magnus and kept in Siena (MS Siena, Biblioteca Comunale degli Intronati, L III I I).

Next to this codicological section, there are three essays dedicated to late medieval texts and their edition or transcription: Roberto Lambertini (Macerata) proposes the transcript of a quodlibetical question written by Peter of Trabibus (MS Firenze, Biblioteca Nazionale Centrale, Conv. Soppr., D. 6.359). This contribution contextualises Peter's question in the traditional Franciscan debate on property and possession, and it highlights the different approaches to the topic followed by Peter of Trabibus and Peter John Olivi.

Another quaestio, this time by Anthony of Parma, is edited by Gianfranco Fioravanti (Pisa): the question is taken from Anthony's commentary on the first book of Avicenna's 
Canon, a commentary that shows the intrinsic Aristotelianism of Anthony's thought. The problem raised by the edited quaestio concerns the relationship between the soul and its powers or virtutes, a topic examined from both a philosophical and a medical point of view.

From medicine to alchemy, the essay of Chiara Crisciani (Pavia) offers a partial transcription of Bernard's commentary to the Rosarius, one of the many alchemical works that has been falsely ascribed to Arnaldus de Villa Nova. This transcription analyses a large portion of the commentary and it is dedicated to the essential features that an alchemist should possess to operate properly: a strong ingenium, dexterity and skill, prudence, sapientia, physical strength, intense study, freedom of research and the financial wealth to support it.

Medicine and alchemy continue to be the central topics of this part of the collection. Some medieval commentaries on the Antidotarium Nicolai are addressed by Iolanda Ventura (Bologna) in her essay on pharmacology: the importance of the Antidotarium, a Salernitan collection of recipes of the half of 12th century, can be best appreciated by considering its numerous commentaries written between the 12th and 13th century. Ventura focuses on four expositions on this work, namely the Liber iste (or Glossae Platearii), the Expositio super Antidotarium Nicolai and two anonymous texts composed in the second half of the 13th century; this analysis allows to further understand the impact of Avicenna's Canon on the pharmacological considerations of the 13th century.

Eleonora Buonocore (Calgary) studies Dante's references to the city of Siena throughout the Divina Commedia, in its comparison to Florence and how the characters coming from Siena (such as Provenzan Salvani and Pia de Tolomei) are depicted. The result is the description of Siena as the purgatorial city par excellence: Siena is linked to the sin of vanity, which opposes the single person to the group and the appearances to the spiritual values. However, through its citizens it also shows the effort toward salvation by redefining their concept of community and overcoming their individual weaknesses.

Gradually leaving the Middle Ages, Mario Meliadò (Freiburg) indulges into the works of Heinrich Cornelius Agrippa, with a special focus on the De incertitudine et vanitate scientiarum (1530). This «negative encyclopaedia» is contextualised in Agrippa's whole philosophical theory, pointing out its purpose, that is, to harshly criticise the medieval educational system; the focal points of the contribution are how Scholasticism is represented by Agrippa and what is the role and the function of the concept of ignorantia. The connection between Agrippa and other thinkers (such as Nicholas of Cusa, Gianfrancesco Pico della Mirandola and Erasmus of Rotterdam) are highlighted both at the end of the essay and in an appendix dedicated to the comparison between Agrippa's Apologia and Nicholas of Cusa's Apologia doctae ignorantiae.

Alchemy comes back on the forefront of this volume with the essays of Ferdinando Abbri (Siena) and Carla Compagno (Freiburg). Abbri considers the figure of Paracelsus, presenting an essential overview of the historiographical debate, dealing with both the history of alchemy and the history of early modern chemistry, up to the contemporary 
reflections. Not only novel critical images of Paracelsus are addressed, but also the popular culture is considered, from literary novels to movies: this operation allows to point out how the interest in Paracelsus varies depending on the historical and cultural moment, as it is the case with Nazi Germany. Compagno dedicates her study to Ivo Salzinger (1669 - 1728), the editor of Lullian Latin texts and a supporter of the alchemical interpretation of Llull's thought. Retracing Salzinger's Perspicia lulliana philosophica, which are part of the third volume of the edition moguntina, Compagno presents Salzinger's understanding of Llull's works in order to take a step further in the research on Lullian pseudography.

Last, a paper on Raimon Panikkar, written by Giuseppe Cognetti (Siena), delves into Panikkar's concept of ecosophy and the relationship between God, Man and Kosmos (Matter), which are aspects that are interrelated and coextensive. The miscellany ends with the bibliography of Michela Pereira, edited by Vincenzo Carlotta (Berlin).

To conclude, this miscellany presents a considerable number of contributes, all of the highest quality, though they span different topics, time periods, and methodological approaches. This significant heterogeneity, however, might be as well a limitation of this volume: while readers may be intrigued by some of the featured essays, it is unlikely that they would appreciate it as a whole. Nevertheless, since Vedere nell'ombra is a tribute to such an important and eclectic scholar as Michela Pereira, its heterogeneity attests to the incredible variety of Pereira's interests. Indeed, it can be regarded as the most important tribute to her distinguished scholarly life. 